\title{
New Zealand's Injury Prevention Research Unit: reducing sport and recreational injury
}

\author{
David J. Chalmers PhD \\ Injury Prevention Research Unit, University of Otago, Dunedin, New Zealand
}

\begin{abstract}
The Injury Prevention Research Unit was established in 1990 to reduce the incidence, severity and consequences of injury. Research into sport and recreational injury is one of five major areas of research being undertaken. National data sources have been used to estimate the overall size of the problem and to describe the nature and circumstances of injury associated with a variety of sport and recreational activities. Analytical studies are now being undertaken to identify significant risk and protective factors. Research activity is being directed toward the development, implementation and evaluation of preventive measures.
\end{abstract}

Keywords: Epidemiology, prevention, recreation

The recognition that injury was a leading contributor to mortality and morbidity in New Zealand ${ }^{1}$ led to the establishment, in 1990, of the Injury Prevention Research Unit (IPRU) at the University of Otago. It is funded jointly by the Health Research Council of New Zealand and the Accident Rehabilitation and Compensation Insurance Corporation (ACC), administrator of New Zealand's compulsory 'accident' compensation and rehabilitation scheme ${ }^{2}$. Its primary aim is to undertake research that will contribute toward reducing the incidence, severity and consequences of injury in New Zealand. Research on sport and recreational injury is one of five major areas of research being undertaken by the IPRU ${ }^{3}$.

Initially the IPRU was involved with describing the nature and extent of the injury problem, using existing data sources. New Zealand is comparatively well placed in this regard, in that - in addition to maintaining a national record of injury fatalities ${ }^{4}-$ it is the only country which maintains a national record of all hospital admissions for injury ${ }^{5}$ and also a national record of compensated claims for medical expenses, rehabilitation, loss of earnings and other costs to individuals sustaining injury ${ }^{6}$. Nevertheless it remains difficult to identify the full extent of injury associated with sport and recreational activity. However, the available data sources suggest that there are on average seven fatalities, approximately 4500 hospitalizations and 92500 emergency depart-

Address for correspondence: David J. Chalmers, Injury Prevention Research Unit, Department of Preventive and Social Medicine, Medical School, University of Otago, PO Box 913, Dunedin, New Zealand

(C) 1994 Butterworth-Heinemann Ltd 0306-3674/94/040221-02 ment attendances each year ${ }^{7}$. In its 1992 financial year, the $A_{C C}^{6}$ paid out over NZ $\$ 98$ million in compensation for sports-associated injuries, including NZ\$33 million on 26183 new claims made in that year.

In addition to estimating the overall size of the problem, attention has been paid to describing the nature and circumstances of injury associated with several specific sporting and recreational activities including injuries from playground equipment ${ }^{8,9}$, trampoline-related injuries ${ }^{10}$, and ankle injuries in sport (particularly netball) ${ }^{11}$. Other research, not confined to sport and recreational activities, has examined cycling ${ }^{12}$, motorcycling ${ }^{13}$, horse-riding ${ }^{14}$, injuries at school ${ }^{15}$, facial fractures ${ }^{16}$ and spinal cord injuries ${ }^{17}$.

The IPRU is also undertaking a number of analytical studies aimed at identifying risk and protective factors for a variety of sport and recreational activities. An investigation of fall-height and impact-surface as risk factors for injury in falls from playground equipment, using a case-control design, is nearing completion ${ }^{18}$. The current major analytical study, known as the Rugby Injury and Performance Project (RIPP) ${ }^{19}$, is using a prospective cohort design, involving 356 players, to identify risk factors and protective mechanisms for injury in rugby. As well as being New Zealand's 'national' sport, rugby (union) has the highest injury incidence of any sport in the country ${ }^{7}$. Finally, while the role of lifestyle factors in disease aetiology has received considerable attention, this has been less the case for injury. The IPRU is undertaking research aimed at determining the significance of lifestyle factors for a variety of injury outcomes, including sport and recreational injury, as part of two major cohort studies known respectively as the Dunedin Multidisciplinary Health and Development Study (DMHDS) ${ }^{20}$ and the Auckland Blood Donor Study (ABDS). The DMHDS involves a cohort of 1037 young adults born in Dunedin in 1972-1973, who have been assessed at regular intervals since the age of 3 years and have provided much valuable information on injury experience ${ }^{21,22}$ and exposure to risk ${ }^{23-25}$ during the formative years. The use of protective behaviours in high-risk sports will also be investigated in this study. Although only at the pilot stage, the ABDS is expected to involve approximately 50000 participants recruited through blood donor services in Auckland, New Zealand's most populous region. 
While most of the research described above has used epidemiological methods, the scope of the IPRU's research is expanding to include other disciplines such as health economics, biomechanics, rehabilitation and health promotion. Collaboration with other agencies is also playing an increasing role in the IPRU's activities. The IPRU is well placed in this regard, with Dunedin being home to New Zealand's only school of physical education and to the national secretariat of the New Zealand Federation of Sports Medicine.

Finally, it is important to note that the IPRU's research activity is directed toward the development, implementation and evaluation of measures that will bring about a reduction in the incidence and severity of injury in New Zealand. In some cases, such as the research on playground and trampoline injuries, this involves input into the development of safety standards. In others, such as the study of rugby injuries, it involves close collaboration with the sport in interpreting the research findings and in developing preventive measures that will be acceptable to players, coaches and officials.

\section{Acknowledgements}

The Injury Prevention Research Unit is funded jointly by the Accident Rehabilitation and Compensation Insurance Corporation and the Health Research Council of New Zealand. The author wishes to acknowledge the contributions of Dr Anna Waller and Dr John Langley to the preparation of this paper. The views expressed in this paper are those of the author and do not necessarily reflect those of the above organizations or individuals.

\section{References}

1 Langley J, McLoughlin E. A Review of Research on Unintentional Injury: A Report to the Medical Research Council of New Zealand (Special Report Series No. 10). Auckland: Medical Research Council of New Zealand, 1987.

2 Accident Rehabilitation and Compensation Insurance Act 1992. Wellington: New Zealand Government, 1992.

3 Injury Prevention Research Unit. Annual Report: For year ending 30 September 1993. Dunedin: Injury Prevention Research Unit, 1994.

4 New Zealand Health Information Service. Mortality and Demographic Data 1991. Wellington: New Zealand Health Information Service, Ministry of Health, 1993.

5 New Zealand Health Information Service. Hospital and Selected Morbidity Data 1992. Wellington: New Zealand Health
Information Service, Ministry of Health, 1993.

6 Accident Rehabilitation and Compensation Insurance Corporation. Injury Statistics 1992. Wellington: Accident Rehabilitation and Compensation Insurance Corporation, 1992.

7 Hume PA, Marshall SW. Sports injuries in New Zealand: exploratory analysis. NZ Sports Med 1994; 22: 18-22.

8 Chalmers DJ, Langley JD. Epidemiology of playground equipment injuries resulting in hospitalisation. J Paed Child Health 1990; 26: 329-34.

9 Kotch JB, Chalmers DJ, Langley JD. Child day care and home injuries involving playground equipment. J Paed Child Health 1993; 29: 222-7.

10 Chalmers DJ, Hume PA, Wilson BD. Trampolines in New Zealand: a decade of injuries. Br J Sports Med 1994; 28: 234-8.

11 Hume PA. Netball injuries in New Zealand. NZ Sports Med 1993; 2: 18-20.

12 Collins BA, Langley JD, Marshall SW. Injuries to pedal cyclists resulting in death and hospitalization. NZ Med J 1993; 106: 514-17.

13 Begg DJ, Langley JD, Reeder AI. Motorcycle crashes in New Zealand resulting in death and hospitalisation I: Introduction, methods, and overview. Accid Anal Prev 1994; 26: 157-64.

14 Buckley SM, Chalmers DJ, Langley JD. Injuries due to falls from horses. Aust I Public Health 1993; 17: 269-71.

15 Langley JD, Chalmers DJ, Collins B. Unintentional injuries to students at school. I Paed Child Health 1990; 26: 323-8.

16 Koorey AJ, Marshall SW, Treasure ET, Langley JD. Incidence of facial fractures resulting in hospitalisation in New Zealand from 1979 to 1988. Int J Oral Maxillofac Surg 1992; 21: 77-9.

17 Dixon GS, Danesh JN, Caradoc-Davies TH. Epidemiology of spinal cord injury in New Zealand. Neuroepidemiol 1993; 12: 88-95.

18 Chalmers DJ, Langley JD, Evans MJ, et al. Height and surfacing as risk factors for injury in falls from playground equipment: a case-control study. In preparation.

19 Waller AE, Feehan M, Marshall SW, Chalmers DJ. The New Zealand Rugby Injury and Performance Project: I. Design and methodology of a prospective follow-up study. $\mathrm{Br} J$ Sports Med 1994; 28: 223-8.

20 Silva PA. The Dunedin Multidisciplinary Health and Development Study; a fifteen year longitudinal study. Perinat Paed Epidem 1990; 4: 76-107.

21 Lodge JF, Langley JD, Begg DJ. Injuries in the 14th and 15th years of life. J Paed Child Health 1990; 26: 316-22.

22 Begg DJ, Langley JD, Chalmers DJ. Bicycle road crashes during fourteenth and fifteenth years of life. NZ Med J 1991; 104: $60-1$.

23 Reeder AI, Stanton WR, Chalmers DJ, Langley JD. Adolescents' sporting and leisure time physical activities during their 15th year. Can I Sports Sci 1991; 16: 308-15.

24 Reeder AI, Chalmers DJ, Langley JD. Motorcycling attitudes and behaviours I: 12 and 14 year old adolescents. J Paed Child Health 1992; 28: 225-30.

25 Reeder AI, Chalmers DJ, Langley JD. Motorcycling attitudes and behaviours II: 14 and 15 year old adolescents. J Paed Child Health 1992; 28: 387-94. 